\title{
The effect of physical distribution service quality on customer perceived value in Omni-channel
}

Nguyen, Thi Dy Anh $₫$

Department of Commerce \& Business Administration, Van Lang University, Ho Chi Minh city, Vietnam (nguyenthidyanh@vanlanguni.edu.vn)

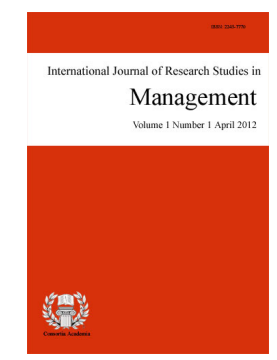

ISSN: $2243-7770$ Online ISSN: 2243-7789

OPEN ACCESS

\section{Abstract}

Physical distribution service quality plays a key role in supply chain management. A successful distribution system will bring high values and profit for company. Through physical distribution service activities, a company can bring good perceived values to customers. Especially, with the development of modern channels, customers have more choices in the buying process. Omni-channel is a modern type of distribution which is used by many companies to access customers more effectively. This research is about the effects of physical distribution service on customer perceived values using Omni-channel. Questionnaires were issued to 200 customers who have experiences in using an Omni-channel to buy products. The results show how customers perceive about physical distribution service quality of companies applied Omni-channel in their supply chain.

Keywords: Physical Distribution Service Quality (PDSQ); physical distribution; supply chain management; Customer Perceived Value (CPV); Omni-channel 


\section{The effect of physical distribution service quality on customer perceived value in Omni-channel}

\section{Introduction}

Physical distribution is the set of activities which support the flow of finished goods from an organization to the consumer. Physical distribution consists of six major functions: transportation, storage and deposit, assembling and processing, material handling, packaging and wrapping, and information chain (Hernández, Garcia, \& Hernández, 2012). Through such activities, the company provides values to customers; they are availability, timeline, condition, flexibility and so on. These values are defined as physical distribution service quality components. Physical distribution service quality (PDSQ) also contributes significantly to the success of supply chain, in general and retail supply chain, in particular. Moreover, the development of different business channels helps consumers have more choices and comforts as well as creates means for companies to get access to consumers. Some modern channels are developed nowadays as multi-channel, Omni-channel. However, this makes the supply chain become more complicated to handle. With the development of Omni-channel, whether companies can run their business in both traditional and modern channels or not. What are the effects of physical distribution service quality on customer perceived value in Omni-channel? The answers of these questions are the objectives of this research.

\section{Literature review}

\subsection{Omni-channel concept}

The Omni-channel is one of the advances of business models in both practice and theories (Bell \& Gallino, 2003). Along with the development of traditional and online stores, new modern selling methods have changed the customer buying habits (Juaneda-Ayensa, Mosquera, \& Sierra Murillo, 2016). Although "the term Omni-channel first appeared six years ago" (Rigby, 2011), the concepts of multi-, cross-, and Omni-channel seem to be easily misunderstood (Beck \& Rygl, 2015; Klaus, 2013), because they also involve in the participation of many members in distribution channels. However, in comparison with multi-channel which operates independently, Omni-channel integrates many channels (traditional and e-commerce) in the same transaction process (Piotrowicz \& Cuthbertson, 2014). Information about customers' buying process will be stored, so that customers can continuously finish their orders whenever they want in Omni-channel (Piotrowicz \& Cuthbertson, 2014). Moreover, Omni-channel distribution helps customers complete a purchase and receive orders from any channel they choose. For example, customers can buy products online or in a physical store in the same retail chain and decide delivery methods that they expect. When they want to return products, the process will take place similarly (Banker \& Cooke, 2013). Omni-channel retailing integrates various channels in store, on the web, and on mobile devices. Customers can easily compare different offers before making decision on where and how to buy something. If a company does not have modern distribution, it can lose customers by competitors.

\subsection{Physical distribution concept}

The concept of physical distribution is discussed by many authors in the world. They realize that a successful physical distribution will be the strength for a company. If a company operates functions in physical distribution efficiently, it will increase profit and gain customers' loyalty. According to Alan, John, and Phil (2010), some typical physical distribution activities are: storage, warehousing and materials handling; transport inventory; information and control; packaging and unitization; location of warehouses number and size of distribution depots type of storage materials handling equipment; unit load protective packaging handling 
The effect of physical distribution service quality on customer perceived value in Omni-channel

systems; design of systems control procedures forecasting; what to stock where to stock how much to stock; mode of transport type of delivery operation load planning route schedule. Council of Logistics Management (CLM) defines physical distribution management as "the systemic, strategic coordination of the traditional business functions and tactics across these businesses functions within a particular organization and across businesses within the supply chain for the purposes of improving the long-term performance of the individual organizations and the supply chain as a whole".

\subsection{Physical distribution service quality (PDSQ) on customer' perspective}

In an early survey of factors which affect industrial buying decisions, Klass (1961) insisted the importance of product factors such as: product quality, delivery performance, quality of salesperson, price, and effective communication. By 1965, the definition of Physical Distribution Service (PDS) could bring new sales opportunities. Stewart (1965) suggested some methods to increase sales volume from 1) minimizing stock-out risks, 2) increasing competitive advantage with shorter customer order cycles, and 3) decreasing prices through effective distribution management.

Rakowski (1982) has proposed different approaches to customer' benefits brought by PDS. Rakowski separates objective measures (speed, availability, accuracy, consistency and product performance) from subjective measures of customers (convenient, flexible, personal attention and information). Although performance measures can be measured more easily by sales, but customer expectations and perceptions are not simple to explain. Coyle (2013) defines: "Customer service is anything that touches the customers. This includes all activities that impact information flow, product flow, and cash flow between the organization and its customers." Alan et al. (2010) supplement Coyle' viewpoint that customers are only interested in results related to their order, their time and psychic energy wasted in seeking a product or service. He suggested that the components related to customer service that physical distribution should satisfy are: product availability, timeliness, flexibility and quality.

Perreault and Russ (1976) maintained that the understanding of physical distribution services from the customer point of view is an important factor in management decisions. Zeithaml (1988) had a similar viewpoint on the concept of perceived quality: "Perceived quality is defined as consumers' judgment about superiority or excellence". While, Mentzer, Gomes, and Krapfel (1989) studied the physical distribution literature to build the model of PDSQ and created a set of items that could act as indicators of PDSQ model. These factors are timeliness, ability, and quality. Quality, in this sense, refers to the form and condition of the delivered order, the status of the delivered products. In short, based on the role of physical distribution services, Mentzer, Gomes, and Krapfel (1989) developed measurement tool on PDSQ that seems to be the dimensions of timeliness, availability and condition.

In 2002, Carol and Lindquist (2002) wrote an article named "e-shopping in a multi-channel environment". They referred an important factor which brings service value to customer that is convenience. Convenience is a critical benefit that e-commerce brings to its customers. Several types of convenience can be considered throughout the shopping process. For instance, products that are easy to reach means "access convenience", while products that are easy to find and to compare shows "search convenience". "Possession convenience" happens when products are easy to get, while acceptance of purchase and return proves shoppers to have "transaction convenience". Meanwhile, "time convenience" is reflected by quickness and without delays of shoppers. Shopping close to home, home delivery and shopping through non-store methods at home mean "place convenience". E-shopping can be fit into one's schedule, and can be started, paused, and resumed when interruptions occur. In addition, search engines enable customers to look for specific product categories, prices, information, and evaluations by experts and users, indicating "search convenience". At the same time, "comparison convenience" permits the e-shopper to take consideration before deciding. As e-shopping can be done at anywhere, it also contributes "energy convenience". Since travel to the store is not required, and all comparisons can be carried out online, customers save the mental and physical energy to look for and evaluate 
alternative choices.

This research selects components of physical distribution on customer views from models suggested by Mentzer, Gomes, and Krapfel (1989), Rushtone, Oxley, and Croucher (2010) and Carol and Lindquist (2002) to develop a research model. They are: product availability, timeliness, condition, flexibility and convenience.

\subsection{Value for customers and customers perceived value}

Value for customers - Philip Kotler emphasizes that customers will choose to buy the goods which they can get the highest value (called value for customers). If the product or service meets customers' needs, they will be loyal. Consequently, they will buy more and repeatedly. In order to attract and retain customers, the company needs to identify the determinants of customer value and satisfaction (Kotler, 2001). Therefore, according to Kotler and Keller (2007), customer value is the difference between the total value a customer receives and the total cost that a customer pays for a product or service. The total value received is all the benefits that a customer expects of a particular product or service, such as product value, service value, personnel value, and image value of the companies. Total cost is the estimated cost of the customer to evaluate and use the product or service, including monetary cost, time cost, mental cost, and labor cost.

Customers Perceived Value (CPV) - Since the late twentieth century, the concept of "perceived value" has been an interest to researchers around the world. It has emerged as an important factor of the survival of the organization. Researchers use a variety of terms to define the perceived value of a customer, such as perceived value, customer value, value for the customer, customer perceived value, perceived customer value, consumer value, consumption value.

One of the authors who spent much time doing research involve in customer perceived values is Zeithaml (1988). She proposed that "Perceived value is the overall appreciation of consumers for the utility of a product or service based on their perception of what is received and what is spent." Zeithaml had a comparison between the two components "get" and "spend" of the product or service. Zeithaml also argues that some consumers feel value when they are offered a low price; others feel value when there is a balance between quality and price. So different consumers will have different perceived value components. A buyer's perception of value is a description of the balance between the quality of the product or the benefit they perceive from the product and the cost they pay for the product (Monroe, as cited in Jyoti Sikka Kainth, 2011).

Another definition derived from Butz and Goodstein (1996). They define that customers perceived value is the emotional relationship established between the customer and the supplier after the customer has used a product or service and sees that the product or service generates added value. Meanwhile, Anderson, Jain and Chintagunta (1993) define customer perceptions as the perceived value of economic, technical, service and social benefits in monetary terms. Those customers can get compared to the price they pay for a product, putting in the price review and offering of the available vendors.

In 1997, Woodruff (1997) supplement previous points of view is that customer perception is the customer's interest, perception, and appreciation of product characteristics, performance, and results from using to easily reach or otherwise interfere with the intent and purpose of the customer in the use case. This concept incorporates the desired value and value and emphasizes that the value comes from the customer's perception, preference and judgment.

Sweeney and Soutar (2001) indicated that there is a need for an enhanced CPV model with better designed measures which can more accurately and completely identify the important values perceived by consumers at a product level or a service level. Through factor analysis using the consumer survey data gathered at both preand post-purchase stages, they identified four distinct dimensions of CPV and specially termed them as PERVAL. They are emotional value, social value, quality/performance value, and price/ value for money, all of which were found to have a significant explanatory power for consumer attitudes and purchase behavior. Since Sweeney and 
The effect of physical distribution service quality on customer perceived value in Omni-channel

Soutar's (2001) CPV study was published, it has been widely cited or applied in numerous conceptual and empirical studies.

CPV for physical distribution service quality is conceptualized as a multidimensional construct. An analytical model was developed based on Sweeney and Soutar (2001)'s framework. Four dimensions in the model, namely emotional value, social value, quality value (performance value), and price value (value for money).

Summary of two conceptual models - customer perceived value model and physical distribution service quality model into model for this research.

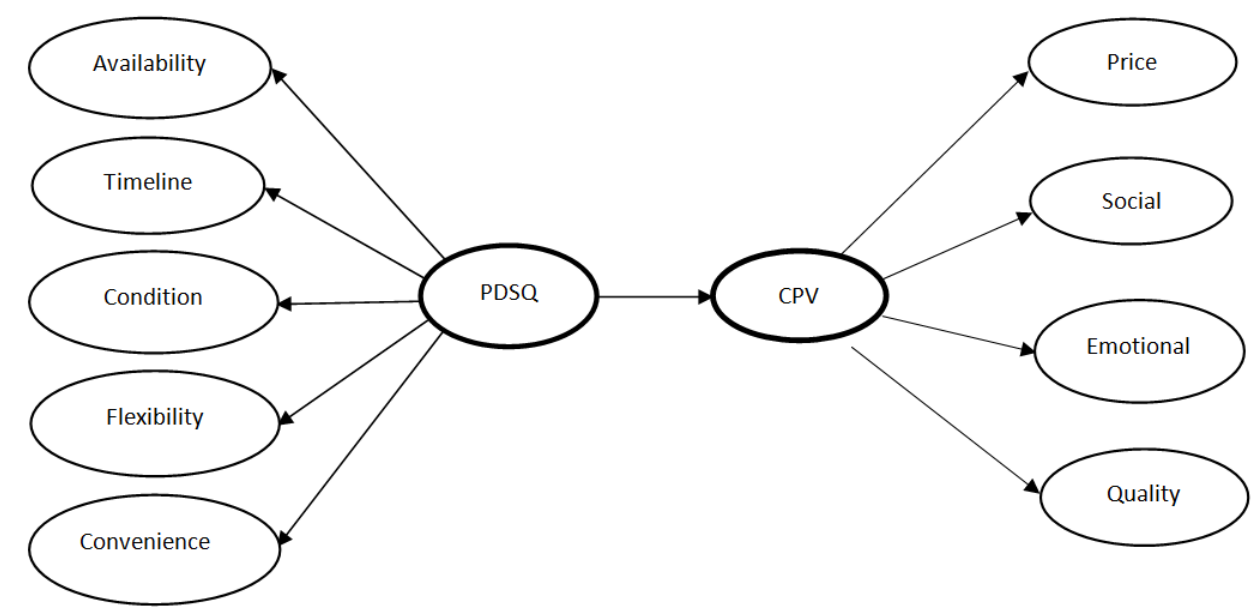

Figure 1. Physical distribution service quality and customer perceived value model

\subsection{Developing hypotheses}

The purpose of this study is to identify components related to PDSQ in Omni channel as well as determinants which compose customer perceived value. On that basis, this study will investigate the effects of PDSQ on customer perceived value in Omni channel. Results of this research might help companies in Omni channel improve their effectiveness and efficiency to upgrade their customers' satisfaction.

From the above description of dependent and independent variables, the following research hypotheses are suggested:

H1: The availability has a positive influence on customer perceived value.

$\mathrm{H} 2$ : The timeline has a positive influence on customer perceived value.

H3: The condition has a positive influence on customer perceived value.

H4: The flexibility has a positive influence on customer perceived value.

H5: The convenience has a positive influence on customer perceived value.

\section{Research methodology}

Qualitative and quantitative approaches were used to design this research. The results of previous empirical researches and group discussion are fundamental for exploring new indicators to adjust and complete the constructs in the research model. The quantitative research applied the survey of consumers who usually use Omni-channel shopping with convenience sampling.

A formal questionnaire with 37 measurement items was set up to measure dimensions of PDSQ (30 items) 
Nguyen, T. D. A.

and CPV (7 items). A 5-point Likert scale (from strongly disagree to strongly agree) was used to indicate the level of agreement to each item of respondents. This structured questionnaire was designed as a data collecting instrument to take advantages of closed-end questions. Participants were the students from the universities in Ho Chi Minh City including Van Lang University, Hutech University, Industry University, and Saigon University. A sample of 220 respondents was targeted and a total of 200 questionnaires were completed with high return rate $91 \%$. Invalid and uncompleted questionnaires were rejected, resulting in 185 valid answer sheets.

Data analysis - Structural Equation Model (SEM), a multivariate technique based on the combination of both factor analysis and regression, has been considered as a data analysis tool. There are two methods: covariance-based techniques (CB-SEM) and variance-based partial least squares (PLS-SEM). However, PLSSEM provides more advantages for researchers when dealing with i) non-normality data set, ii) minimum demand of sample size. Therefore, PLS-SEM is superior to CB-SEM in this situation.

\section{Research results}

\subsection{Cronbach's Alpha test}

The results of reliability testing with Cronbach's Alpha coefficient show that the components of the scale are presented in Table 1. The results of testing the components of the scale have Cronbach's Alpha $>0.6$ and there are not measurement variables having correlations less than 0.3 . Thus, 37 observed variables continue to be included in the exploratory factor analysis (EFA).

\section{Table 1}

Cronbach's Alpha Reliability Analysis

\begin{tabular}{|c|c|c|c|}
\hline Reliability & Mean & $S D$ & $\begin{array}{l}\text { Cronbach's Alpha } \\
\text { if Item Deleted }\end{array}$ \\
\hline A wide assortment of products is available & 3.96 & .865 & .741 \\
\hline Products are available & 3.74 & .889 & 697 \\
\hline Retailer has inventory availability near my facility & 3.79 & .879 & .697 \\
\hline Order status information is readily available & 4.13 & .797 & .708 \\
\hline The retailer demonstrates equipment prior to order placement & 3.98 & .878 & .715 \\
\hline If products are out of stock, the replace products are available & 3.82 & .930 & .745 \\
\hline Cronbach's Alpha & .753 & & \\
\hline Timeline & Mean & $S D$ & $\begin{array}{l}\text { Cronbach's Alpha } \\
\text { if Item Deleted }\end{array}$ \\
\hline The order placement time is short & 3.80 & .890 & .712 \\
\hline Backorder time is short & 3.79 & .915 & .708 \\
\hline The delivery time is specifically indented & 4.12 & .745 & .721 \\
\hline The time between placing and receiving an order is short & 3.78 & .794 & .688 \\
\hline The time it takes my retailer to put my order together is consistent & 3.77 & .934 & .711 \\
\hline Products ordered are delivered on time & 3.84 & .928 & .704 \\
\hline Delivery is rapid & 3.84 & .870 & .807 \\
\hline Cronbach's Alpha & .754 & & \\
\hline Condition & Mean & $S D$ & $\begin{array}{l}\text { Cronbach's Alpha } \\
\text { if Item Deleted }\end{array}$ \\
\hline All of products are delivered at the same time & 3.84 & .870 & .654 \\
\hline Products are delivered as required & 4.00 & .885 & .586 \\
\hline Products are in good quality as described & 3.91 & .849 & .574 \\
\hline Products are package safely and conveniently & 4.01 & .831 & 693 \\
\hline Cronbach's Alpha & 694 & & \\
\hline Flexibility & Mean & $S D$ & $\begin{array}{l}\text { Cronbach's Alpha } \\
\text { if Item Deleted }\end{array}$ \\
\hline Order policy is flexible & 3.96 & .836 & .678 \\
\hline Products are updated according to market demand & 3.97 & .824 & .611 \\
\hline Retailer can meet special requirement of customer & 3.88 & .864 & .628 \\
\hline The pay back and exchange policy is simple & 3.85 & .876 & .740 \\
\hline Cronbach's Alpha & .727 & & \\
\hline
\end{tabular}


The effect of physical distribution service quality on customer perceived value in Omni-channel

Table 1 ... continued

\begin{tabular}{|c|c|c|c|}
\hline Convenience & Mean & $S D$ & $\begin{array}{l}\text { Cronbach's Alpha } \\
\text { if Item Deleted }\end{array}$ \\
\hline Location is easy to access & 3.97 & .833 & .834 \\
\hline Easy to find website of retailer & 4.12 & .801 & .820 \\
\hline Easy to find products on retailer' website & 4.15 & .807 & .817 \\
\hline Can order products at any time & 4.16 & .741 & .827 \\
\hline $\begin{array}{l}\text { When order process is interrupted, it can be continued at any time without } \\
\text { losing information }\end{array}$ & 4.10 & .777 & .821 \\
\hline There is always support from counselors & 3.80 & .871 & .830 \\
\hline Can decide where to receive products & 4.16 & .791 & .822 \\
\hline Can follow order status & 4.22 & .657 & .842 \\
\hline Can compare products from different online retailers & 3.94 & .854 & .835 \\
\hline Cronbach's Alpha & .844 & & \\
\hline Customer perceived value & Mean & $S D$ & $\begin{array}{l}\text { Cronbach's Alpha } \\
\text { if Item Deleted }\end{array}$ \\
\hline Price is reasonable & 3.88 & .750 & .803 \\
\hline Product is value in comparison with money spent & 3.97 & .762 & .794 \\
\hline The fee is reasonable & 3.91 & .799 & .816 \\
\hline Can save time and effort & 4.19 & .726 & .809 \\
\hline Can get the attention and good service & 3.98 & .783 & .795 \\
\hline Can catch market trends thanks to information from website & 3.95 & .845 & .795 \\
\hline Retailer provides high service value for customer & 4.01 & .744 & .786 \\
\hline Cronbach's Alpha & .823 & & \\
\hline
\end{tabular}

\subsection{Exploratory factor analysis}

An exploratory factor analysis (EFA) is performed to evaluate the validity of the measurement scales of all variables. Total 37 items are used to analyze exploratory factor and include two parts. Part 1 consists of 30 items to present PDSQ in Omni channel, and part 2 with 7 items to show CPV. The KMO of dimensions of PDSQ in part 1 is 0.896 , and its Barlett's test p-value is 0.000. The KMO of CPV in part 2 is 0.871 , and its Barlett's test $\mathrm{p}$-value is 0.000 . The test values indicate that the data are accepted to perform further factor analysis. Then in part 1, we use principal component analysis method and variable maximization rotation to maintain 32 items. Their factor loadings are shown in Table 4. The table shows seven common factors extracted from the remaining 37 items. Cumulative extraction sum of squared loading is $59.301 \%$ (part 1) and $51.877 \%$ (part 2).

Twenty nine factors loadings are above 0.5 and no-cross construct loadings are above 0.3 , indicating good validity of discrimination. Some other factors have loading factor of variables which are less than 0.5 , so they are removed from the model (Nunnally \& Bernstein, 1994). After removal, from the original 6 elements with 37 observed variables are adjusted into 7 factors with 29 observed variables. Among them, four variables including CONV26, CONV27, CONV28, CONV29 which were belong to Convenience factor are grouped in Customer Service factor and renamed as CS26, CS27, CS28, in turn.

\section{Table 2}

KMO and Barlett's Test of PDSQ variables

\begin{tabular}{lll}
\hline KMO and Bartlett's Test & \\
Kaiser-Meyer-Olkin Measure of Sampling Adequacy. & .896 \\
Bartlett's Test of Sphericity & Approx. Chi-Square & 2199.703 \\
& df & 435 \\
& Sig. & .000 \\
\hline
\end{tabular}

Table 3

KMO and Barlett's Test of CPV variables

\begin{tabular}{lll}
\hline KMO and Bartlett's Test & \\
Kaiser-Meyer-Olkin Measure of Sampling Adequacy. & .871 \\
Bartlett's Test of Sphericity & Approx. Chi-Square & 366.135 \\
& df & 21 \\
& Sig. & .000 \\
\hline
\end{tabular}


Nguyen, T. D. A.

Table 4

Factor analysis

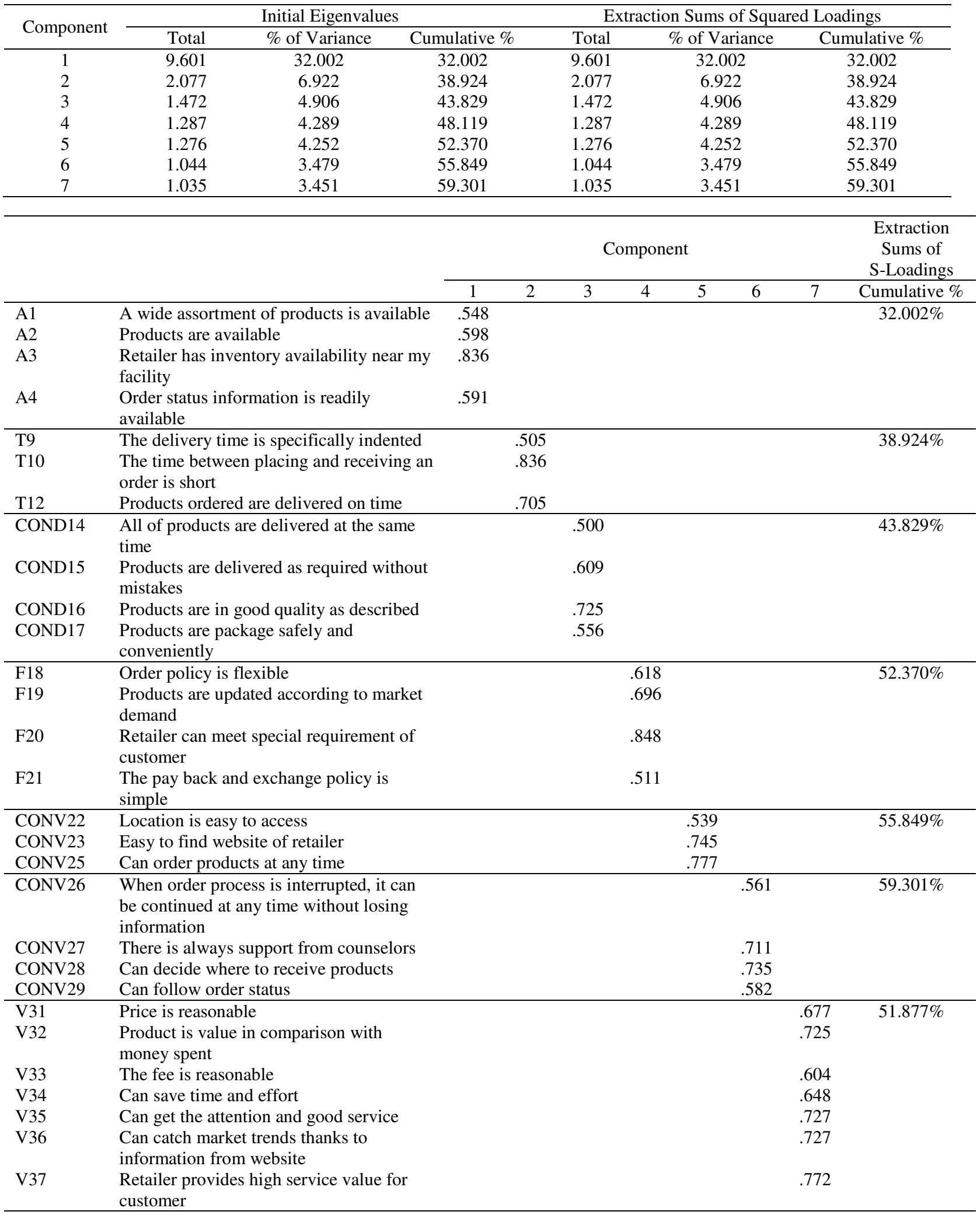

\subsection{Analysis of linear structure model (SEM)}

The method of analyzing linear structure model (SEM) by SmartPLS software is used to verify the research 
The effect of physical distribution service quality on customer perceived value in Omni-channel

model. Model to test the impact of 7 factors: Availability, Timeline, Condition, Flexibility, Convenience, Customer Service, Customer Perceived Value.

Evaluation of the measurement Model - The requirements of evaluating reflective measurement model include: internal consistency reliability, indicator reliability, convergent validity, discrimination validity. In particular, Cronbach's alpha (CA) must be more than 0.6 and composite reliability (CR) must be more than 0.7 (Hair et al., 2014). Moreover, indicator reliability must be more than 0.5, this means outer reliability should be more than 0.7. In addition, Average Variance Extracted (AVE) is greater than 0.5 to confirm the reliability and the convergence validity of the scale. This research also uses Heterotrait-monotrait ratio; Fornell-Lacker, and Cross Loadings to analyze discriminant validity.

The analytical results show that some variables did not meet these requirements, so that they were removed from the model. The remaining variables meet the requirements, so they are streamlined into 14 variables to measure PDSQ and 4 variables to measure CPV. These factors and variables are shown in Figure 2.

Figure 2. SEM analysis result

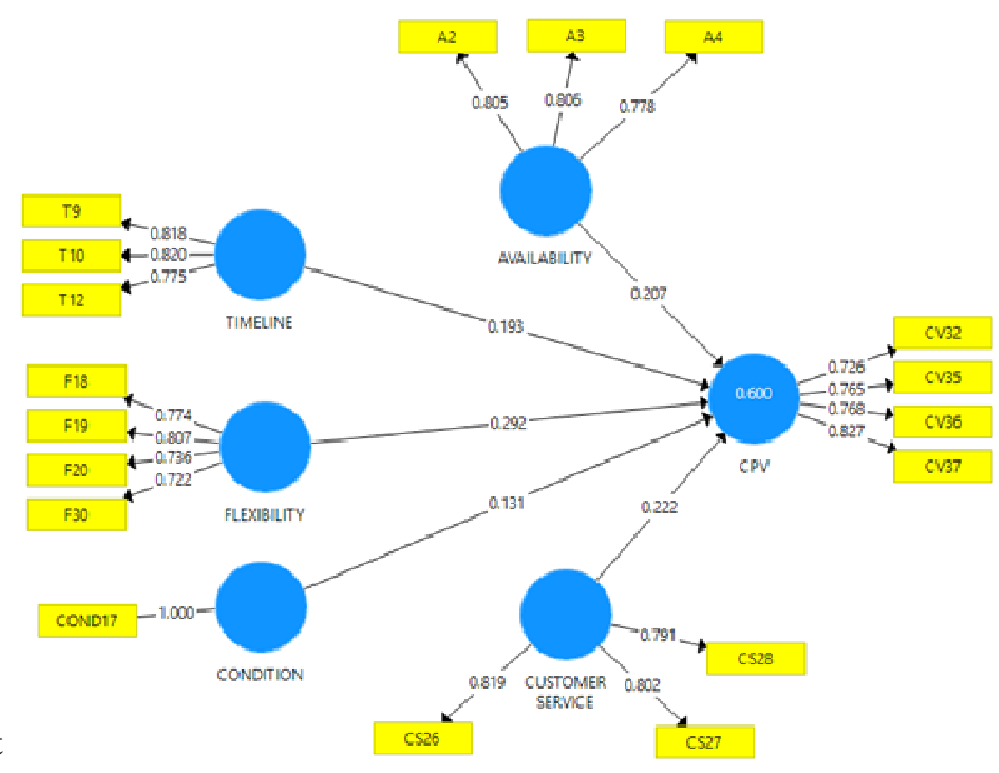

The results presented in table 5 show that all factors have Cronbach alpha $>0.6$ and AVE (average variance extracted) $>0.5$. This means the reliability and validity of these factors is valuable. Results from table 6 show that all outer loadings of constructs Availability, Condition, Customer Service, CPV, Flexibility and Timeline are higher than permitted threshold $(>0.708)$.

\section{Table 5}

Construct Reliability and Validity

\begin{tabular}{lcccc}
\hline & Cronbach's Alpha & Rho A & $\begin{array}{c}\text { Composite } \\
\text { Reliability }\end{array}$ & $\begin{array}{c}\text { Average Variance } \\
\text { Extracted (AVE) }\end{array}$ \\
\hline AVAILABILITY & 0.711 & 0.712 & 0.839 & 0.634 \\
CONDITION & 1.000 & 1.000 & 1.000 & 1.000 \\
CUSTOMER SERVICE & 0.730 & 0.736 & 0.846 & 0.647 \\
CPV & 0.773 & 0.776 & 0.855 & 0.596 \\
FLEXIBILITY & 0.756 & 0.758 & 0.846 & 0.578 \\
TIMELINE & 0.728 & 0.729 & 0.846 & 0.647 \\
\hline
\end{tabular}

Table 7 refers to Fornell- Larcker criteria. According to these criteria, $\sqrt{\text { AVE }}$ of each research variables is more than correlation value of this variable with others in model. Results prove that all $\sqrt{ }$ AVE of research variables meet that requirement. While, Table 8 involves in Cross Loading results. All cross loadings of variables are higher than their crossing loadings with others in model. Therefore, this criterion is valid.

Discrimination values appear in Table 9. All HTMT values are less than 0.85. This indicates that all 
Nguyen, T. D. A.

constructs are distinguished with each other. With results discussed above, this measurement model is accepted for further steps.

\section{Table 6}

Outer Loadings

\begin{tabular}{|c|c|c|c|c|c|c|}
\hline & AVAILABILITY & CONDITION & $\mathrm{CPV}$ & $\begin{array}{c}\text { CUSTOMER } \\
\text { SERVICE } \\
\end{array}$ & FLEXIBILITY & TIMELINE \\
\hline A2 & 0.805 & & & & & \\
\hline A3 & 0.806 & & & & & \\
\hline A4 & 0.778 & & & & & \\
\hline COND17 & & 1.000 & & & & \\
\hline CS26 & & & & 0.819 & & \\
\hline CS27 & & & & 0.802 & & \\
\hline CS28 & & & & 0.791 & & \\
\hline CV32 & & & 0.728 & & & \\
\hline CV35 & & & 0.766 & & & \\
\hline CV36 & & & 0.766 & & & \\
\hline CV37 & & & 0.826 & & & \\
\hline F18 & & & & & 0.774 & \\
\hline F19 & & & & & 0.807 & \\
\hline F20 & & & & & 0.736 & \\
\hline F30 & & & & & 0.722 & \\
\hline $\mathrm{T} 10$ & & & & & & 0.820 \\
\hline $\mathrm{T} 12$ & & & & & & 0.775 \\
\hline T9 & & & & & & 0.818 \\
\hline
\end{tabular}

Table 7

Fornell - Larcker Criterion

\begin{tabular}{|c|c|c|c|c|c|c|}
\hline & AVAILABILITY & CONDITION & $\begin{array}{c}\text { CUSTOMER } \\
\text { SERVICE }\end{array}$ & $\mathrm{CPV}$ & FLEXIBILITY & TIMELINE \\
\hline AVAILABILITY & 0.796 & & & & & \\
\hline CONDITION & 0.209 & 1.000 & & & & \\
\hline CUSTOMER SERVICE & 0.427 & 0.342 & 0.804 & & & \\
\hline $\mathrm{CPV}$ & 0.561 & 0.384 & 0.611 & 0.772 & & \\
\hline FLEXIBILITY & 0.464 & 0.252 & 0.549 & 0.633 & 0.760 & \\
\hline TIMELINE & 0.502 & 0.311 & 0.495 & 0.585 & 0.472 & 0.804 \\
\hline
\end{tabular}

Table 8

Cross Loadings

\begin{tabular}{lcccccc}
\hline & AVAILABILITY & CONDITION & $\begin{array}{c}\text { CUSTOMER } \\
\text { SERVICE }\end{array}$ & CPV & FLEXIBILITY & TIMELINE \\
\hline A2 & 0.805 & 0.156 & 0.351 & 0.443 & 0.414 & 0.494 \\
A3 & 0.806 & 0.173 & 0.331 & 0.462 & 0.287 & 0.430 \\
A4 & 0.778 & 0.171 & 0.338 & 0.435 & 0.411 & 0.273 \\
C32 & 0.484 & 0.292 & 0.458 & 0.728 & 0.442 & 0.462 \\
C35 & 0.387 & 0.317 & 0.521 & 0.766 & 0.434 & 0.451 \\
C36 & 0.405 & 0.318 & 0.409 & 0.766 & 0.520 & 0.388 \\
C37 & 0.455 & 0.264 & 0.496 & 0.826 & 0.556 & 0.501 \\
COND17 & 0.209 & 1.000 & 0.342 & 0.384 & 0.252 & 0.311 \\
CS26 & 0.358 & 0.319 & 0.819 & 0.513 & 0.376 & 0.408 \\
CS27 & 0.362 & 0.249 & 0.802 & 0.537 & 0.474 & 0.420 \\
CS28 & 0.302 & 0.255 & 0.791 & 0.405 & 0.484 & 0.359 \\
F18 & 0.340 & 0.219 & 0.485 & 0.469 & 0.774 & 0.345 \\
F19 & 0.413 & 0.143 & 0.426 & 0.507 & 0.807 & 0.407 \\
F20 & 0.355 & 0.092 & 0.313 & 0.434 & 0.736 & 0.362 \\
F30 & 0.304 & 0.299 & 0.436 & 0.508 & 0.722 & 0.322 \\
T10 & 0.405 & 0.198 & 0.366 & 0.478 & 0.387 & 0.820 \\
T12 & 0.419 & 0.332 & 0.510 & 0.510 & 0.395 & 0.775 \\
T9 & 0.382 & 0.208 & 0.296 & 0.411 & 0.350 & 0.818 \\
\hline
\end{tabular}


The effect of physical distribution service quality on customer perceived value in Omni-channel

Table 9

Heterotrait-Monotrait Ratio (HTMT)

\begin{tabular}{|c|c|c|c|c|c|c|}
\hline & AVAILABILITY & CONDITION & $\begin{array}{c}\text { CUSTOMER } \\
\text { SERVICE }\end{array}$ & $\mathrm{CPV}$ & FLEXIBILITY & TIMELINE \\
\hline \multicolumn{7}{|l|}{ AVAILABILITY } \\
\hline CONDITION & 0.248 & & & & & \\
\hline CUSTOMER SERVICE & 0.587 & 0.399 & & & & \\
\hline CPV & 0.756 & 0.439 & 0.801 & & & \\
\hline FLEXIBILITY & 0.635 & 0.285 & 0.738 & 0.824 & & \\
\hline TIMELINE & 0.692 & 0.358 & 0.660 & 0.770 & 0.632 & \\
\hline
\end{tabular}

Table 10

Outer and Inner VIF Values

\begin{tabular}{lc}
\hline \multicolumn{2}{c}{ Outer VIF Values } \\
\hline & VIF \\
\hline A2 & 1.433 \\
A3 & 1.402 \\
A4 & 1.347 \\
C32 & 1.354 \\
C35 & 1.502 \\
C36 & 1.533 \\
C37 & 1.734 \\
COND17 & 1.000 \\
CS26 & 1.493 \\
CS27 & 1.340 \\
CS28 & 1.548 \\
F18 & 1.549 \\
F19 & 1.742 \\
F20 & 1.518 \\
F30 & 1.323 \\
T10 & 1.615 \\
T12 & 1.265 \\
T9 & 1.693 \\
\hline
\end{tabular}

\begin{tabular}{|c|c|c|c|c|c|c|}
\hline \multicolumn{7}{|c|}{ Inner VIF Values } \\
\hline & AVAILABILITY & CONDITION & $\begin{array}{c}\text { CUSTOMER } \\
\text { SERVICE }\end{array}$ & $\mathrm{CPV}$ & FLEXIBILITY & TIMELINE \\
\hline AVAILABILITY & & & & 1.494 & & \\
\hline CONDITION & & & & 1.169 & & \\
\hline CUSTOMER & & & & 1.687 & & \\
\hline SERVICE & & & & & & \\
\hline CPV & & & & & & \\
\hline FLEXIBILITY & & & & 1.635 & & \\
\hline TIMELINE & & & & 1.626 & & \\
\hline
\end{tabular}

Table 11

$R$ square

\begin{tabular}{lcc}
\hline & R Square & R Square Adjusted \\
\hline CPV & 0.600 & 0.588 \\
\hline
\end{tabular}

Evaluation of the Structural Model - Standards to evaluate structural model in PLS-SEM are: Collinearity assessment (VIF should be less than 5), coefficients of determination (R2), predictive relevance (Q2), size and significance of path coefficients, f2 effect sizes and q2 effect sizes. Table 10 indicates that VIF values including outer VIF value and Inner VIF Values are less than 5, this mean they do not violate the criteria of Multi-collinearity testing (Hair et al., 2010). Results from table 11 to table 13 show that all variables in the model are in the permitted scope. The adjusted $\mathrm{R}$ square is 0.588 , which means that $58.8 \%$ of CPV is explained by 5 factors in PDSQ. The effect level of each factor is shown in table 12 and table 13. Among them, the Flexibility and Customer Service factor have the highest effect level on CPV. 
Nguyen, T. D. A.

Table 12

F square

\begin{tabular}{|c|c|c|c|c|c|c|}
\hline & AVAILABILITY & CONDITION & $\begin{array}{c}\text { CUSTOMER } \\
\text { SERVICE }\end{array}$ & $\mathrm{CPV}$ & FLEXIBILITY & TIMELINE \\
\hline AVAILABILITY & & & & 0.072 & & \\
\hline CONDITION & & & & 0.037 & & \\
\hline CUSTOMER SERVICE & & & & 0.073 & & \\
\hline CPV & & & & & & \\
\hline FLEXIBILITY & & & & 0.130 & & \\
\hline TIMELINE & & & & 0.057 & & \\
\hline
\end{tabular}

Table 13

Path coefficient

\begin{tabular}{|c|c|c|c|c|c|c|}
\hline & AVAILABILITY & CONDITION & $\begin{array}{c}\text { CUSTOMER } \\
\text { SERVICE }\end{array}$ & CPV & FLEXIBILITY & TIMELINE \\
\hline AVAILABILITY & & & & 0.207 & & \\
\hline CONDITION & & & & 0.131 & & \\
\hline CUSTOMER SERVICE & & & & 0.222 & & \\
\hline $\mathrm{CPV}$ & & & & & & \\
\hline FLEXIBILITY & & & & 0.291 & & \\
\hline TIMELINE & & & & 0.193 & & \\
\hline
\end{tabular}

Bootstrapping test - To be able to extrapolate the results of the study, the model needs to be re-tested for reliability. The topic uses bootstrapping with a repeated sample size of 1000 observations $(n=1000)$ with an initial sample size of 185 observations. The estimated results from 1000 observations indicate that the original weight has significant meaning for the average weight of bootstrapping because all weights are within the $95 \%$ confidence interval. Thus, the estimates in the model may conclude as reliable.

\section{Table 14}

Bootstrapping test

\begin{tabular}{lccccc}
\hline & $\begin{array}{c}\text { Original } \\
\text { Sample }(\mathrm{O})\end{array}$ & Mean $(\mathrm{M})$ & SD (STDEV) & $\begin{array}{c}\text { T Statistics } \\
\text { (|O/STDEVI) }\end{array}$ & $p$ Values \\
\hline AVAILABILITY $\rightarrow$ CPV & 0.207 & 0.206 & 0.067 & 3.084 & .002 \\
CONDITION $\rightarrow$ CPV & 0.131 & 0.135 & 0.060 & 2.208 & .027 \\
CUSTOMER SERVICE $\rightarrow$ CPV & 0.222 & 0.219 & 0.069 & 3.208 & .001 \\
FLEXIBILITY $\rightarrow$ CPV & 0.292 & 0.296 & 0.068 & 4.273 & .000 \\
TIMELINE $\rightarrow$ CPV & 0.193 & 0.193 & 0.070 & 2.760 & .006 \\
\hline
\end{tabular}

\subsection{Hypothesis test}

As presented above, this research includes 5 hypothesizes. The results of bootstrapping show that these 5 hypothesis effect on CPV with $\alpha$ (level of significance) $=5 \%$. Results of hypothesizes are showed in Table 14 and Figure 2.

Hypothesis H1 supposes that the Availability has a positive influence on CPV. The availability factor includes 5 variables at first, but after being tested by Exploratory Factor Analysis and PLS SEM, two variables were deleted. Therefore, 3 remaining variables (A2, A3, A4) represent for Availability factor. The Availability factor has a strong influence on CPV with $\beta=0.207$; $t$-value $=3.084$ and $p$ value $=.002$. This means the availability of products, the available status of order information and the availability of shops which are near customers' location will help customers perceive high value provided by retailers.

Hypothesis $\mathrm{H} 2$ suggests that the Timeline has a positive influence on CPV. The timeline factor includes 7 variables at first, but after being tested by Exploratory Factor Analysis and PLS SEM, 4 variables are deleted because they can't meet the requirement suggested in measurement model. Therefore, 3 remaining variables (T9, T10, T12) represent for Timeline factor. The timeline factor quite strongly influences on CPV with $\beta=0.193$; 
The effect of physical distribution service quality on customer perceived value in Omni-channel

$t$-value $=2.760$ and $p$ value $=.006$. Customers expect that the time between placing and receiving an order is consistent. They also require that the delivery time is specifically identified and all orders are delivered on time. This shows that timeline is one of the elements which customers lay stress on. It is also a competitive advantage that company should pay attention to compete with competitors.

Hypothesis $\mathrm{H} 3$ insists that the Condition of the order has a positive influence on CPV. The condition factor includes 4 variables at first, but after being tested by Exploratory Factor Analysis and PLS SEM, 3 variables are deleted because they can't meet the requirement suggested in measurement model. Therefore, 1 remaining variables (COND17) represent for Condition factor. That variable is "Product is packaged conveniently and safely" with $\beta=0.131 ; t$-value $=2.208$ and $p$ value $=.027$. Any customer hopes that products will be safe when receiving. To do so, designing package to protect the content of products as well as ensure the convenience for customers is a vital requirement for company. Besides, the aesthetic element should be paid attention.

Hypothesis H4 believes that the Flexibility has a positive influence on CPV. The Flexibility factor includes 4 variables at first, but after being tested, 1 variable are deleted. Therefore, 3 remaining variables (F18, F19, F20, F21) represent for Flexibility factor. The Flexibility has a highest effect level on CPV with $\beta=0.292 ; t$-value $=$ 4.273 and $p$ value $=.000$. This means that if a retailer has some advantages such as the order policy is flexible, the products are updated to market demands, the ability to satisfy customers' specific requirements and product return or exchange policy is simply, that retailer will increase the customers' satisfaction.

Hypothesis H5 shows that the Convenience factor which is divided into to 2 parts after Exploratory Factor Analysis stage (part 1 still keeps Convenience name and part 2 is renamed Customer Service) has a strong influence on CPV. Three elements of Convenience factors including CONV22, CONV23, CONVE25 are removed from model because their coefficients of Cronbach alpha are less than 0.7 and they cannot have the level of significance at 5\% when bootstrapping. Therefore, 3 remaining variables (CS26, CS27, CS28) represent for Customer Service factor. The Customer Service factor has the second strong influence on CPV with $\beta=$ $0.222 ; t$-value $=3.208$ and $p$ value $=.001$. In particular, customers will be pleased when their ordering process is interrupted by some private reasons, they still keep products information in shopping cart and they can continue their ordering at any time and by any means (computer, mobile, laptop). This is an outstanding advantage in Omni channel. This research proves that customers appreciate the value that this advantage brings to. Moreover, the fact that there is always support from counselors when customers get trouble is a critical element in customer service. Besides, when customers actively decide where to receive the product (they can come to the shop of retailer or they want retailer to ship a specific location as they require), they feel that they get benefits from retailer in comparison with what they pay.

\section{Conclusion}

This study determines that there are five dimensions of PDSQ influencing on CPV. . The product availability, timeline, flexibility, condition and customer service have positive influence on customer perceived value in Omni channel. Managers should concentrate on these factors to create competitive advantage and attract more customers in Omni channel. Managers should pay much attention on the flexibility of PDSQ because this factor contributes greatly on customer perceived value. Customer's satisfaction will be increased when retailer makes flexible condition for them in purchasing. Some characteristics of flexibility are "order policy is flexible", "the products are updated to market demands", "retailer has ability to satisfy customers' specific requirements" and "product return or exchange policy is simple". Managers can boost these characteristics to increase customer perceived value.

One important thing in PDSQ is Customer service. Customers will be pleased when ordering process is quick and safe. They also want to get recommendation from counselors as well as to decide where they receive products (at home or in the shop, for example). This is also benefits of Omni channel business. Therefore, managers should take advantage these strengths in market competition. Besides, retailers should ensure the 
product availability, the timeline to process order as well as to deliver products, and the good quality of product. These three factors make a great contribution on customer perceived value, because availability and speed are two weapons to get competitive advantage in the competition nowadays. Managers should consider factors which are belong to customer perceived value. Customers will satisfy when the value they received is worth with what they spend; or when they received good customer service from counselors. Moreover, through information from website, they can update newest trends in market. Therefore, managers need to provide good PDSQ to increase $\mathrm{CPV}$.

Limitation - This study has quite small sample size. The survey is taken place in Ho Chi Minh City. Future studies can perform larger sample size and widen geographic area to gain higher generalizability.

\section{References}

Alan, R., John O., \& Phil C. (2010). Handbook of logistics and distribution management. London: Kogan Page Publisher.

Alexander, H., Andreas, H., \& Heinrich, K. (2016). Distribution systems in omni-channel retailing. Business Research, 9, 255-296. https://doi.org/10.1007/s40685-016-0034-7

Anderson, J. C., Jain, D. C., \& Chintagunta, P. K. (1993). Customer value assessment in business markets: A state of practice study. Journal of Business to Business Marketing, 1(1), 3-29. https://doi.org/10.1300/J033v01n01_02

Banker, S., \& Cooke, J.A. (2013). Stores: The weak link in Omni channel distribution. Retrieved from http://www.dcvelocity.com/articles/20130805-stores-the-weak-link-in-omnichannel-distribution/

Beck, N., \& Rygl, D. (2015). Categorization of multiple channel retailing in multi-, cross-, and omni-channel retailing for retailers and retailing. Journal of Retailing and Consumer Services, 27, 170-178. https://doi.rog/10.1016/j.jretconser.2015.08.001

Bell, R. D., Gallino, S., \& Moreno, A. (2014). How to win in an omnichannel world. Sloan Management Review, $56(1), 45-53$.

Butz, H., \& Goodstein, L. (1996). Measuring customer value: gaining the strategic advantage. Organizational Dynamics, 24(3), 63-77. https://doi.org/10.1016/S0090-2616(96)90006-6

Coyle, J. J. (2013). Supply chain management: A logistics perspective ( $9^{\text {th }}$ ed.). Nashville: South-Western College Pub.

Hair, J. F., Hult, G. T. M., Ringle, C. M., \& Sarstedt, M. (2014). A Primer on Partial Least Squares Structural Equation Modeling (PLS SEM) ( $2^{\text {rd }}$ ed.). CA: Sage Publisher.

Hernández, J. G., García, M. J., \& Hernández, G. J., (2012). Enterprise logistics, indicators and physical distribution managers. Research in Logistics and Production, 3(1), 5-20.

Juaneda-Ayensa, E., Mosquera, A., \& Sierra Murillo, Y. (2016). Omni channel customer behavior: Key drivers of technology acceptance and use and their effects on purchase intention. Frontiers in Psychology, 7(125), 1-11. https://doi.org/10.3389/fpsyg.2016.01117

Jyoti, S. K. (2011). Consumer perceived value: Construct apprehension and its evolution. Journal of Advanced Social Research, 1, 20-57.

Kaufman-Scarborough, C., \& Lindquist, J. D. (2002). E-shopping in a multiple channel environment. Journal of consumer marketing, 19(4), 333-350. https://doi.org/10.1108/07363760210433645

Klaus, P. (2013). Exploring online channel management strategies and the use of social media as a market research tool. International Journal of Market Research, 55(6), 829-850. https://doi.org/10.2501/IJMR-2013-069

Kotler, P. (2001). Marketing management. New Jersey: Prentice Hall.

Kotler, P., \& Keller, L. (2007). Marketing management. New Delhi India: Practice Hall.

Mentzer, J. T, Gomes, R., \& Krapfel, R.E. (2009). Physical distribution service: A fundamental marketing concept? Journal of the Academy of Marketing Science, 17(1), 53-62.

https://doi.org/10.1177/009207038901700107 
The effect of physical distribution service quality on customer perceived value in Omni-channel

Moberg, C. R., Cutler, B. D., Gross A., \& Speh T. W. (2002). Identifying antecedents of information exchange within supply chains. International Journal of Physical Distribution and Logistics Management, 32(9), 755-770. https://doi.org/10.1108/09600030210452431

Monroe, K. B., \& Grewal, D. (1991). Effects of price, brand and store information on buyers' product evaluation. Journal of Marketing Research, 28(3), 307-319. https://doi.org/10.1177/002224379102800305

Mosquera, A., Olarte Pascual, C. Y., \& Juaneda Ayensa, E. (2017): Understanding the customer experience in the age of Omni-channel shopping. Icono, 15(2), 166-185. https://doi.org/10.7195/ri14.v15i2.1070

Parasuraman, A., Zeithaml, V. A., \& Berry, L. L. (1998). Serqual: A multiple-item scale for measuring consumer perceptions of service quality. Journal of Retailing, 64(1), 12-40.

Perreault, W. D., \& Russ, F. A. (1976). Physical distribution service in industrial purchase decisions: A survey of industrial purchasing. Journal of Marketing, 40(2), 3-10. https://doi.org/10.2307/1251000

Piotrowicz, W., \& Cuthbertson, R. (2014). Introduction to the special issue information technology in retail: toward omnichannel retailing. International Journal of Electronic Commerce, 18(4), 5-16. https://doi.org/10.2753/JEC1086-4415180400

Rakowski, J. P. (1982). The customer service concept. Business and Economic Research, 17(4), 55-66.

Rigby, D. (2011). The future of shopping. Harvard Business Review, 89(12), 65-76.

Robert, B. W. (1997). Customer value: the next source for competitive advantage. Journal of the Academic of Marketing Science, 25(2), 139-153. https://doi.org/10.1007/BF02894350

Stewart, M. W. (1965). Physical distribution: keys to improve volume and profits. Industrial Marketing, 29(1), 65-70. https://doi.org/10.1177/00222496502900115

Sweeney, J. C., \& Soutar, G. N. (2001). Consumer perceived value: The development of a multiple item scale. Journal of Retailing, 77(2), 203-220. https://doi.org/10.1016/S0022-4359(01)00041-0

Tan, K. C., Lyman, S. B, \& Wisner, J. D. (2002). Supply chain management: A strategic perspective. International Journal of Operations and Production Management, 22(6), 614-631. https://doi.org/10.1108/01443570210427659

Thao, H. T. P., \& Hai, N. N. T. (2016). The effect of perceived benefits and perceived risks on intention to shop apparel online by white - collar women in Vietnam. Journal of Science Ho Chi Minh City Open University, 19(3), 11-22.

Thao, H. T. P., \& Hai, N. N. T. (2018). Impact of online social media on consumers' purchasing intention via social network sites. Journal of Science Ho Chi Minh City Open University, 8(2), 56-71.

Uzel, J. M. M (2018). Effect of physical distribution practices on the performance of kappa oil refineries limited, Mombasa, Kenya. Strategic Journals, 5(2), 2190-2204.

Woodruff, R. B. (1997). Customer value: the next source for competitive advantage. Academy of Marketing Science Journal, 25(2), 139-153. https://doi.org/10.1007/BF02894350

Zeitham, A. V. (1988). Consumer perception of prices, quality and value: A mean-end model and synthesis of evidence. Journal of Marketing, 52(3), 2-22. https://doi.org/10.1177/002224298805200302 
Nguyen, T. D. A. 